\title{
Students Utilization on Quipper LMS: A Mixed Method
}

\author{
Jeanilyn E. Tacadena, Ph.D ${ }^{1}$, Mariesel A. Laurel, Ed.D ${ }^{2}$, Amelie L. Chico, Dm, Frim ${ }^{3}$ \\ ${ }^{1,2}$ College Professor/Program Head-BEED, College of Teacher Education, University of Mindanao - Panabo College, Panabo \\ City \\ ${ }^{3}$ College Professor/Research Coordinator, University of Mindanao - Panabo College, Panabo City
}

\begin{abstract}
COVID-19 is a global concern affecting the educational system in Higher Education Institution. As such Quipper-LMS became a resource in delivering quality education in the new normal learning. This study paved to examine students acceptance in Quipper-LMS as new way to deliver learning among students in UM Panabo. Results showed that there is a high acceptance of Quipper-LMS in terms of social influence, performance expectancy, effort expectancy and facilitating conditions. This is also affirmed from the qualitative responses of students, however sensitivity of the system be address.
\end{abstract}

Keywords: Quipper-LMS, social influence, performance expectancy, effort expectancy facilitating conditions, acceptance level, and UM Panabo, Philippines.

\section{INTRODUCTION}

$\mathrm{T}$ he COVID-19 pandemic is first and foremost a health crisis. Many countries have rightly decided to close schools, colleges and universities. The crisis crystallises the dilemma policymakers are facing between closing schools, reducing contact and saving lives. Crisis has also made an impact on the context of Philippine Education were classes are postponed due to lockdown and majority of the colleges and universities faced current challenges in online modality or with virtual learning (Talindong \& Toquero, 2020).

Moreover, education is no exception. It affects people regardless of nationality, level of education, income or gender. This crisis has exposed the many inadequacies and inequities in our education systems - from access to the broadband and computers needed for online education, and the supportive environments needed to focus on learning, up to the misalignment between resources and needs. (Scheler, 2020).

With this status, teaching is moving online, on an untested and unprecedented scale. Although the concept on the use of internet based platforms in education is not something new. Such was the case for Muico (2019) in using youtube as well as Fleck, B. K., Richmond, A. S., and Hussey, H. D. (2013) in using social media. However student assessments are also moving online bringing with it a lot of trial and error and uncertainty for everyone. Many assessments have simply been cancelled. Importantly, these interruptions will not just be a short-term issue, but can also have long-term consequences for the affected cohorts and are likely to increase inequality (Burgess \& Sievertsen, 2020). The transition of the new normal learning came to several adjustment from its readiness in online education and utilization of LMS platforms. Considering the relevance of the above condition, and students concern on their internet connection, this study aimed to identify the extent of acceptance of DTE students in using quipper LMS in delivering the instruction.

\section{METHODS}

To identify the extent of acceptance of students utilization in the quipper LMS. This study employs a sequential explanatory method. Respondents and participants were students from the Department of Teacher Education. The researchers conducted the study during the $2^{\text {nd }}$ semester of School Year 2020-2021. Students' respondents were determined using the computed sample size. Online platforms were used in gathering of data, for quantitative phase google survey forms were sent to students group chats and in-depth interview using google meet for the qualitative phase. The set of question was adapted from the study of (Sezer \& Yilmaz,2019) and was modified to suit in the context of the study. The study involve only those students who had access to the internet. There were a total of 190 students who responded in the online survey and 6 students responded for an interview question.

\section{RESULTS AND DISCUSSION}

\section{Extent of Students Acceptance in Quipper LMS}

From the significant number of respondents the study shows the extent of students' acceptance of quipper LMS with the over-all mean of 3.99 which is attributed as High. This is also supported by Wallis, L. (2020) that college students who enrolled in online or distance learning and never attend faceto-face are comfortable in communicating through technology and managing their learning without showing up in a particular place or time.

In particular Social Influence got the highest mean of 4.04 which means as High. This is also evident from the study of Olasina, G. (2018), that social influence, attitude and perceived usefulness, stress, satisfaction and fatigue are critical to behavioral intention to accept e-learning thus, recognizing human, social and cultural components make it possible to improve e-learning experiences of users. Performance Expectancy got a mean of 3.99 which is interpreted as High. Literature shows that student's belief in 
using LMS improves their performance and enables them to adopt its use readily (Raza, S., Qaz, W., Khan, K., \& Salam, J., 2020).

Effort Expectancy and Facilitating Conditions got the same mean of 3.96 which is interpreted as High. This is also supported from the study of Alshehri A., Rutter, M., and Smith S., (2020) which states that both has direct positive influence on students' behavioral intention to use an LMS.

\begin{tabular}{|c|c|c|}
\hline Item & Mean & Remarks \\
\hline \multicolumn{3}{|l|}{ Performance Expectancy } \\
\hline $\begin{array}{l}\text { Using the QUIPPER LMS in my classes enables } \\
\text { me to accomplish the tasks given by my teachers } \\
\text { more quickly. }\end{array}$ & 4.19 & High \\
\hline $\begin{array}{l}\text { Using the QUIPPER LMS in my classes improves } \\
\text { my performance as a student. }\end{array}$ & 3.86 & High \\
\hline $\begin{array}{l}\text { Using the QUIPPER LMS in my classes improves } \\
\text { my work productivity as a student. }\end{array}$ & 3.97 & High \\
\hline $\begin{array}{l}\text { Using the QUIPPER LMS in my classes improves } \\
\text { my work motivation as a student. }\end{array}$ & 3.94 & High \\
\hline $\begin{array}{l}\text { Using the QUIPPER LMS in my classes improves } \\
\text { learning in my day to day activity. }\end{array}$ & 3.91 & High \\
\hline $\begin{array}{l}\text { I find using the QUIPPER LMS in my subjects } \\
\text { useful. }\end{array}$ & 4.14 & High \\
\hline $\begin{array}{l}\text { Using the QUIPPER LMS in my classes enhances } \\
\text { the effectiveness of the learning process. }\end{array}$ & 3.92 & High \\
\hline Mean & 3.99 & High \\
\hline \multicolumn{3}{|l|}{ Effort Expectancy } \\
\hline $\begin{array}{l}\text { I find learning how to use the QUIPPER LMS } \\
\text { easy and manageable. }\end{array}$ & 4.12 & High \\
\hline $\begin{array}{l}\text { In actual, I can easily use the QUIPPER LMS } \\
\text { without interruptions. }\end{array}$ & 3.79 & High \\
\hline $\begin{array}{l}\text { I can accomplish tasks more quickly when I use } \\
\text { the QUIPPER LMS. }\end{array}$ & 4.05 & High \\
\hline I feel comfortable when using the QUIPPER LMS. & 4.00 & High \\
\hline $\begin{array}{l}\text { I can do anything I want using the QUIPPER } \\
\text { LMS. }\end{array}$ & 3.86 & High \\
\hline Mean & 3.96 & High \\
\hline \multicolumn{3}{|l|}{ Facilitating Conditions } \\
\hline $\begin{array}{l}\text { I have the required information to make effective } \\
\text { use of the QUIPPER LMS. }\end{array}$ & 4.04 & High \\
\hline $\begin{array}{c}\text { There are people I can turn to for support when I } \\
\text { have difficulty using the QUIPPER LMS. }\end{array}$ & 4.04 & High \\
\hline $\begin{array}{l}\text { Using the QUIPPER LMS is similar to using other } \\
\text { LMS platforms. }\end{array}$ & 3.80 & High \\
\hline $\begin{array}{l}\text { When using the QUIPPER LMS I know whom to } \\
\text { ask for help to solve problems I encounter. }\end{array}$ & 4.02 & High \\
\hline $\begin{array}{l}\text { The help function of the QUIPPER LMS is } \\
\text { sufficient to solve the problem I encounter. }\end{array}$ & 3.92 & High \\
\hline Mean & 3.96 & High \\
\hline \multicolumn{3}{|l|}{ Social Influences } \\
\hline $\begin{array}{l}\text { People around me think that it is important for me } \\
\text { to make effective use of the QUIPPER LMS. }\end{array}$ & 3.98 & High \\
\hline $\begin{array}{l}\text { My effective use of the QUIPPER LMS increases } \\
\text { my prestige as a student who experience online } \\
\text { classes. }\end{array}$ & 4.06 & High \\
\hline $\begin{array}{l}\text { Using QUIPPER LMS gives advantage and } \\
\text { prestige in doing the expected tasks as a student. }\end{array}$ & 4.08 & High \\
\hline Mean & 4.04 & High \\
\hline Overall Mean & 3.99 & High \\
\hline
\end{tabular}

\section{Qualitative Result on Students Acceptance in Quipper-LMS}

Philippine education system faces unprecedented challenges as they rethink their approach and brace for the new normal (Bersamina \& Relativo 2020). Moreover, the expectancy of the users of Quipper-LMS during pandemic increases. Result from the qualitative affirmed that DTE students have positive feedback on the utilization of the LMS. The following were given emphasis on the Performance Expectancy (develop students sense of responsibility, easy access to daily activities and allows students to study in advance) Effort Expectancy (accomplish the task timely and features are easy to utilize/user friendly) Social Influence (convenient and efficient to use, personnel were very approachable, improves students technical skills) and Facilitating Conditions (assistance from the personnel and sensitivity of the system). This is a manifestation that students are adapting to the new changes in the educational system. Thus online learning is becoming a huge catalyzer for people and companies to help the adoption of this rapid change in the world. (Koksal 2020).

\section{IV.CONCLUSION AND RECOMMENDATIONS}

As institutions seek to minimize the potential for community transmission, the utilization of LMS be given top priority as it delivers quality learning for students. Based from the findings, Quipper LMS had a high satisfaction to it's users, as it brings big help to learners who are having a tough time during pandemic. Quipper LMS among DTE students has improved sense of responsibility and provides a more flexible learning environment that enables better management of their learning. Moreover, the result of the study shows positive impact on the acceptance of students to utilize quipper LMS. Thus, sensitivity features inside the quipper LMS be addressed by the quipper personnel. It is also recommended that teachers may sustain effective utilization of quipper LMS.

\section{REFERENCES}

[1] Alshehri, A, Rutter, M. \& Smith, S. (2020). The Effects of UTAUT and Usability Qualities on Students' Use of Learning Management Systems in Saudi Tertiary Education. Retrieved from Volume 19, Number 1, Jan 28, 2020 ISSN 1539-3585 Publisher: Informing Science Institute

[2] Bersamina \& Relativo(2020): Life After Lockdown: Maassive Shift to Online Education Widens Digital Gap Between Rich and Poor Life After Lockdown: How schools and classes will be like in the Philippines | Philstar.com

[3] Burgess S. \& Sieverten H. (2020) Scchool, Skills, and Learning: The Impact of Covid 19 on Education. Retrieved from The impact of COVID-19 on education | VOX, CEPR Policy Portal (voxeu.org)

[4] Debrock,Scagnoli \& Dutta(2020). The Human Element in Online Learning Retrieved from./www.insidehighered.com/advice/2020/03/18/how-makeonline-learning-more-intimate-and-engaging-students-opinion

[5] Fleck, B. K., Richmond, A. S., \& Hussey, H. D. (2013). Using social media to enhance instruction in higher education. In Research perspectives and best practices in educational technology integration (pp. 217-241). IGI Global.

[6] Koksal I. (2020) The Rise Of Online Leaning. Retrieved from The Rise of Online Learning (forbes.com)

[7] Muico, E. J. (2019). A Quintesential Tool in Teaching: A Case Study on Teachers Using YouTube Videos. International Journal 
for Innovation Education and Research, 7(8), 40-46. https://doi.org/10.31686/ijier.vol7.iss8.1647

[8] Norman S. (2016) 5 Advantages Of Online Learning: Education Without leaving Home. Retrieved from 5 Advantages Of Online Learning: Education Without Leaving Home - eLearning Industry

[9] Olasina, G (2018). Human and social factors affecting the decision of students to accept e-learning. Retrieved from (PDF) Human and social factors affecting the decision of students to accept e-learning (researchgate.net)

[10] Raza, S., Qaz, W., Khan, K., \& Salam, J. (2020). Social Isolation and Acceptance of the Learning Management System (LMS) in the time of COVID-19 Pandemic: An Expansion of the UTAUT Model. Retrieved from Social Isolation and Acceptance of the Learning Management System (LMS) in the time of COVID-19 Pandemic: An Expansion of the UTAUT Model - Syed A. Raza, Wasim Qazi, Komal Akram Khan, Javeria Salam, 2021 (sagepub.com)

[11] Scheler A. (2020) THE IMPACT OF COVID-19 ON EDUCATION INSIGHTS FROM EDUCATION AT A GLANCE
2020. Retrieved from the-impact-of-covid-19-on-educationinsights-education-at-a-glance-2020.pdf (oecd.org)w=

[12] Sezer, B. and Yilmaz, R. (2019). Learning management system acceptance scale (LMSAS): A validity and reliability study. Retrieved from Learning management system acceptance scale (LMSAS): A validity and reliability study | Australasian Journal of Educational Technology (ajet.org.au)

[13] Talindong A.\& Toquero C.(2020) V2020 July 9 Philippine Education Is in Crises. V 2020 July 9 Philippine education in crisis Retrieved from | Course Hero

[14] Wallis L. (2020) Growth in Distance Learning Outpaces Total Enrollment Growth. Retrieved from Growth in Distance Learning Outpaces Total Enrollment Growth - Article Display Content QualityInfo 